\title{
KUALIFIKASI POLITIK UANG DAN STRATEGI HUKUM DAN KULTURAL ATAS PENCEGAHAN POLITIK UANG DALAM PEMILIHAN UMUM
}

\author{
Muhammad Hoiru Nail \\ Program Doktor Ilmu Hukum Fakultas Hukum Universitas Jember \\ Email: hoirunail88@gmail.com
}

\begin{abstract}
Abstrak
Pemilihan umum secara garis besar ialah tindakan yang dilakukan oleh negara yang sah untuk mendapatkan pemimpin dalam sebuah negara (jabatan politik), ketentuan mengenai penyelenggaran pemilu sudah diatur melalui peraturan perundang-undangan, namun tidak sedikit dalam penyelenggaran pemilu, peserta pemilihan umum melakukan politik uang untuk memenangkan kompetisi tersebut. Tindakan politik uang harus diformulasikan dengan baik agar tindakan politik uang dapat benar-benar sesuai dengan hakikat politik uang. Tindakan penggantian uang transportasi, uang lelah dan uang makan dalam mobilisasi pemilih dalam kampanye terbuka perlu penegasan dari kajian ilmu hukum. Instumen hukum terhadap pencegahan politik uang harus dikaji secara mendalam, penerapan hukum pidana sebagai ultimum remidium harus dikaji secara mendalam, beberapa cara lainnya dapat digunakan sebagai metode pencegahan politik uang selain mekanisme hukum yang ada.
\end{abstract}

\section{Kata kunci: kualifikasi, Politik Uang, Mobilisasi Pemilih}

\begin{abstract}
Abstrak
General election is an action taken by a legitimate state to get a leader in a country (political position), the provisions concersing the holding of general elections have been regulated through legislation, but not a little in the holding of general elections, general election pasticipans did money politics to win the competition. Money politic must be well formulated so that money politiccan be trully in accordance with the naturale of money politic. The act of reimbursing tranportation money, tired money, and food money in mobilizing voters inan open campaign needs confirmation from law. Legal instument in the prevention of money politic must be studied in depth the apllication of the criminal law as un ultimum remidium must be studied in depth, several ather ways can be used as metholds of prevention of money politic in addition to existing legas mechanisms.
\end{abstract}

\section{Keywords: Qualification, Money Politic, Voter Mobilization}

\section{A. Pendahuluan}

\section{Latar Belakang}

Sebagai bentuk dari pengakuan atas klaim negara hukum, ${ }^{1}$ maka segala tindakan/penyelenggaraan negara dalam bingkai Negara Kesatuan Republik Indonesia dilakukan dengan atau melalui mekanisme hukum itu sendiri. Oleh karenanya tindakan

1 Pasal 1 Ayat (3) UUD NRI Tahun 1945 "Negara Indonesia adalah Negara Hukum” 
tindakan penyelenggaraan pemerintahan oleh negara/pemerintahan yang sah semuanya dilakukan dengan mekanisme pengaturan oleh hukum. Hal yang demikian menurut Jimly Asshiddiqie disebut dengan the rule of law, and not of Man atau hukumlah yang memegang komando tertinggi dalam penyelenggaraan sebuah negara. ${ }^{2}$ Implikasi atas pengakuan/klaim negara hukum dan pula menempatkan hukum sebagai komando tertinggi dalam penyelenggaran negara, maka semua aspek penyelenggaraan pemerintahan tersebut diatur secara tegas melalui instumen hukum/peraturan perundang-undangan, termasuk dalam hal ini ialah pengaturan mengenai pemilihan umum (Pemilu).

Negara sebagai sebuah institusi, maka penyelenggaraan negara didalamnya dibutuhkan orang/pejabat yang diberikan kewenangannya oleh Peraturan Perundangundangan untuk menjalankan sebuah pemerintahan, termasuk pula perlu diatur mengenai mekanisme pengisian jabatan atas post-post jabatan tertentu/jabatan politik melalui mekanisme pemilihan umum yang dilakukan dengan cara demokratis atau melibatkan peran serta masyarakat/pemilih sebagai pemegang kedaulatan demokrasi dalam pemilihan umum. Sehingga diperlukan pengaturan hukum yang sedemikian baik agar pemilu yang hendak diselenggarakan dapat berjalan dengan baik, lancar dan yang terpenting menghasilkan pemimpin-pemimpin terbaik untuk bangsa ini.

Mahfud MD mengatakan bahwa demokrasi atau pemilihan umum tidak serta merta dilakukan dengan semaunya tanpa adanya hukum yang mengatur, Demokrasi harus berjalan sesuai dengan prosedur hukum. ${ }^{3}$ Menurut abdul gaffar pemilu merupakan kebutuhan yang sangat penting dalam peradaban demokrasi, pemilu merupakan syarat yang sangat dominan yang harus dimiliki oleh negara ketika dalam pergaulan internasional. ${ }^{4}$ Mekanime pengisian jabatan tersebut diatur melalui peraturan Perundang-undangan yang secara langsung melibatkan masyarakat sebagai penentu atas seseorang yang dianggap pantas menduduki jabatan politik tersebut.

Menurut Benjuino Theodore sebagaimana dikutip oleh Agus Riwanto, istilah sistem pemilihan umum atau Pemilu memiliki definisi yang sangat ketat yakni sistem

2 Jimly Asshiddiqie, Konstitusi \& Konstitusionalisme Indonesia, Jakarta: Sinar Grafika, 2010, hlm. 57.

3 Mahfud MD, Konstitusi dan Hukum dalam Kontoversi Isu, Jakarta: PT. Raja Grafindo Persada, 2012, hlm. 41 .

4 Abdul Gaffar, Pemilu: Sebiah Token of Membership, Yogyakarta: Laboratorium JIP UGM, 2009, hlm. V-VI. 
pemilihan umum ialah serangakaian kegiatan yang diatur menurut peraturan perundangundangan yang menurutnya terdapat 2 aspek besar didalamnya. Pertama, Pemilih mengekpresikan pilihan politiknya, Kedua suara dari pemilih dapat diterjemahkan sebagai sebuah kekuasaan atau kursi/jabatan politik tertentu. ${ }^{5}$ Dalam konteks pemilu di Indonesia, pemilu atau Pemilihan umum adalah rangkaian kegiatan yang dilakukan oleh Komisi Pemililihan Umum (KPU) guna menghasilkan jabatan-jabatan politik tertentu (presiden/wakil presiden, Gubernur/wakil gubernur, bupati,wakil bupati, walikota dan wakil walikota serta anggota legislatif baik dari pusat hingga daerah provinsi,kabupaten/kota, selanjutnya pengaturan Secara konstitusional mengenai pemilihan umum tersebut diatur didalam pasal 22E UUD NRI Tahun 1945. Dengan mekanisme tersebut maka nantinya pejabat-pejabat yang terpilih melalui proses pemilihan umum melaksanakan tugas/amanat rakyat melalui kewenangan-kewenangan yang diberikan oleh Peraturan Perundang-undangan.

Dalam penyelenggaraan pemilu terdapat asas yang harus dijalankan dengan baik, yakni asas langsung, umum, bebas, rahasia, jujur dan adil. Penulis berpikir kelima asas tersebut memiliki kedudukan yang sama dalam menghasilkan pejabat yang berintegritas tinggi, namun dalam hal ini penulis lebih mengkhususkan penulisannya pada terlaksanannya asas jujur dan adil. Sebab diketahui bersama bahwa dalam beberapa penyelenggaraan pemilu yang telah dilakukan sejak pertama kali diadakan (tahun 1955) hingga saat ini, angka pelanggraan pemilu tertinggi ialah terkait politik uang. ${ }^{6}$

Dengan demikian dibutuhkan cara untuk menanggulangi pelanggaran politik uang tersebut, agar pejabat yang dihasilkan merupakan pejabat yang dihasilkan oleh pemilihan umum yang bersih dan berintegritas serta memenuhi kelima asas pemilihan umum tersebut. Hal ini diperlukan sebab jika tidak ditemukan cara yang benar (jujur dan adil) maka akan terjadi ketidakadilan, calon perserta pemilu dapat menggunakan kekuatan finansial yang tinggi untuk mengalahkan calon yang tidak/lemah dalam hal finasial.

5 Agus Riwanto, Hukum Partai Politik dan Hukum Pemilu di Indonesia, Yogyakarta: Thafa Media, 2016, hlm. 53.

6 Berdasarkan rilis yang dilakukan oleh Bawaslu, Indeks Kerawanan Pemilu (IKP) atas penyelenggaran pilkada serentah tahun 2018, praktik politik uang merupakan pekanggaran tertinggi. Lihat Berita Satu, "Bawaslu: Pencegahan Politik Uang juga Butuh Partisipasi Masyarakat," http://www.beritasatu.com/politik/46570-bawaslu-pencegahan-politik-uang-juga-butuh-partisipari-rakyat

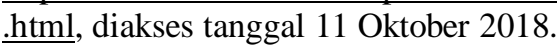


Sebenarnya, instumen hukum telah mengantasisipasi hal tersebut (instumen hukum pidana) dengan memberikan larangan terhadap politik uang, pelanggaran atas politik setidaknya terdapat dua penyelesaiaan, yakni penyelesaain sanksi administrasi dan pidana oleh kepolisian. ${ }^{7}$ Namun dalam melakukan pencegahan atas tindakan politik uang menurut hemat penulis tidak hanya instument hukum yang ada pada saat ini, namun perlu cara-cara pencegahan lain yang efektif guna terciptanya pemilihan umum yang bersih.

Sejatinya praktik politik perlu dihindari dikarenakan secara hakikat pemilu yang hendak dilakukan dapat menghasilkan pemimpin yang memiliki kompetensi yang mumpuni, memiliki legitimasi dalam arti yang sesungguhnya, serta memiliki kepekaan yang tinggi atas rakyatnya kelak. ${ }^{8}$ Dalam hal legitimasi yang sesungguhnya itulah yang sebenarnya tidak akan didapat oleh peserta pemilu yang menggunakan cara-cara yang salah/tindakan politik uang, sedangkan pemimpin-pemimpin yang dihasilkan atas hasil politik uang itupun akan menghasilkan pemimpin yang korup yang dapat diprediksi dalam masa kepemimpinanya akan berusaha dengan berbagai cara untuk menutupi modal yang telah dikeluarkannya pada saat pemilihan.

Hal lain yang perlu dipertegas oleh penulis dalam tulisannya kali ini ialah terkait pengertian politik uang itu sendiri, sebab tidak dapat dipungkiri pesta demokrasi/pemilihan umum dibelahan bumi mana saja memang membutuhkan uang/modal baik oleh penyelenggara maupun peserta pemilu itu sendiri, sehingga diperlukan sebuah pemahaman yang sama terkait tindakan apa dan bagaimana politik uang (money politic) dapat dikategorikan sebagai sebuah tindakan pelanggaran pemilu dan bahkan masuk dalam kategori pidana pemilu. Misalkan saja pada saat masa kampanye, peserta pemilu/calon Presiden atau wakil presiden diberikan waktu dan ruang untuk melakukan kampanye terbuka dan menghadirkan massa/masyarakat dalam jumlah yang besar pula, dilain hal kedatangan masyarakat ke tempat kampanye diberikan sejumlah uang oleh peserta pemilu, apakah dalam hal tersebut pemberian jumlah uang tersebut dapat dikategorikan dalam kegiatan politik uang, hal-hal yang

7 Lihat pasal 93, 94 ayat 3 bagian c UU No 7 tahun 2017 tentang Pemilihan Umum. "tugas bawaslu ialah mencegah politik uang" "bawaslu memeriksa, mengkaji, dan memutus pelanggaran politik uang. "

8 Indah Sri Utami, "Pencegahan Politik Uang dan Penyelenggaraan Pilkada yang Berkualitas:Sebuah Revitalisasi Ideologi,” Seminar Nasional Hukum, Vol. 2 No. 1 2016, hlm. 452. 
seperti ini perlu penegasan yang baik dan benar berdasarkaan sudut pandng ilmu hukum.

Setiap negara memiliki ciri khas dan kebudayaan yang berbeda, khususnya terkait budaya hukumnya. Dalam konteks ini tentu penanganan pencegahan politik uang (money politic) di negara Indonesia haruslah didekati berdasarkan kultur masyarakat atau kultur kebudayaan yang diyakoni kebenarannya oleh masyarakat indonesia, yang dalam hal ini indonesia lebih dikenal dengan kultur masyarakat yang religius, dari hal tersebut tentu harus diformulasikan secara baik agar cara yang digunakan dapat efektif dapat menangggualangi pencegahan politik uang dalam pemilu.

Hal-hal lain yang juga menjadi fokus penulis dalam hal ini ialah, apakah instumen hukum tentang pencegahan terjadinya politik uang sudah senyatanya efektif dan terbukti, setidaknya mengurangi pelanggaran politik uang. Dalam lain hal sebenarnya terdapat perbaikan dari segi pengaturan hukum itu sendiri, agar hukum benar-benar menjadi cara "ultimum remidium/ cara/jalan terakhir" dalam pencegahan politik uang. Apakah setiap orang sudah mengetahui akan hukum bagi pemberi dan penerima politik uang dalam pemilu, dan apakah masih ada cara lain selain instument hukum yang ada tersebut dapat digunakan sebagai penanganan pencegahan politik uang dalam pemilu di indonesia mengingat kultur rakyat indonesia yang religius. Kedua hal tersebut menjadi fokus pembahasan dalam tulisan ini.

\section{Rumusan Masalah}

Berdasarkan pendahuluan tersebut diatas, maka permasalahan yang diangkat dalam tulisan ini ialah, pertama, apakah tindakan mendatangkan massa/masyarakat dalam jumlah yang besar pada kegiatan kampanye terbuka dengan memberikan uang kepada masyarakat dapat dikategorikan politik uang. Kedua, apakah instrumen hukum terkait pencegahan politik uang sudah efektif dan bagaimana strategi kultural pencegahan politik uang.

\section{B. Pembahasan}

Pertama Untuk menjawab permasalah pertama ini, penulis akan memulainya dengan menyampaikan argumentasi tentang pemilu membutuhkan uang/modal. Dimanapaun, dan kapanpun pemilu diselenggarakan, baik penyelenggaraan maupun 
peserta pemilu tidak dapat dipungiri membutuhkan biaya tidak tidak sedikit, oleh karena mustahil dalam ajang pemilu peserta pemilu tidak mengeluarkan uang/modal dalam keikutsertannya dalam pemilu. Bahkan menteri dalam negeri juga menyampaikan hal yang sama, bahwa seorang calon bupati atau waklikota setidaknya memerlukan modal atau ongkos politik 20 sampai 100 milyar dalam keikutsertaanya dalam pemilu. ${ }^{9}$ Dengan demikian tidak dapat dipungkiri bahwa keikutsertaan peserta pemilu atau kepala daerah memerlukan biaya/modal, tidak menjadi sebuah persoalan ketika modal terebut benar-benar digunakan untuk kepentingan pemenangan dalam arti sesungguhnya (pembelian atribut, iklan, kaos dan lainnya yang dibenarkan dalam pemilu), namun tidak sedikit dari peserta pemilu dengan ambisi yang sangat besar menggunakan caracara yang dilarang semisal dengan melakukan tindakan politik uang (money politic).

John Raws memperkenalkan sebuah filosofi tentang keadilan yang disebut dengan konsep keadilan "fairness", konsep ini mengandung asas bahwa orang-orang yang memiliki kemerdekaan dan rasionalitas serta memiliki kehendak untuk mengembangkan kepentingannya haruslah memperoleh sebuah kedudukan yang sama pada saat hendak memeulai sebuah kompetisi. ${ }^{10}$ Keadilan dan kejujuan dalam pemilu haruslah dikedepankan, oleh karenanya penelitian ini berusaha memberikan jawaban atas keadilan bagi peserta pemilu dan kejujuran yang harus dilakukan oleh peserta pemilu dalam keikutsertaannya dalam pemilu, dengan berdasarakan konsep keadilan fairness dari Jons Raws tersebut diharapkan semua peserta pemilu memulai sebuah kedudukan dari tempat yang sama, perlakuan yang sama, termasuk tindakan-tindakannya haruslah sesuai dengan apa yang telah menjadi sebuah aturan dalam pemilu.

Pengertian politik uang (money politic) itu sendiri menurut ketentuan Peraturan perundang-undangan ialah "setiap orang dengan sengaja melakukan perbuatan melawan hukum menjanjikan uang atau materi lainnya sebagai imbalan kepada warga negara indonesia baik secara langsung maupun tidak langsung untuk mempengaruhi pemilih agar tidak menggunakan hak pilih dengan cara tertentu sehingga suara menjadi tidak sah, memilih calon tertentu, atau tidak memilih calon tertentu sebagaimana dimaksud pada pasal 73 ayat (4) dipidana dengan pidana penjara paling singkat 36 (tiga puluh enam) bulan dan denda paling sedikit Rp. 200.000.000 dua ratus

9 Kompas.com, "Mahalnya Ongkos Politik," Nasional.kompas.com/read/2018/01//12/0949 4501/mahalnya-ongkos-politik, diakses tanggal 11 Oktober 2018.

10 John Raws, Theory of Justice, Cambridge: Harvard University Press, 1971, hlm. 11. 
juta rupiah) dan paling banyak Rp. 1.000.000.000 (satu miliar rupiah). ${ }^{11}$ Berdasarkan bunyi pasal tersebut dapat ditarik kesimpulan bahwa peserta pemilu dapat dikatakan melakukan tindakan pemilu apabila a. Dengan sengaja b. Menjanjian uang/materi lainnya baik langsung atau tidak langsung, c. Untuk mempengaruhi tidak menggunakan hak pilih (menjadi tidak sah)/memilih calon tertentu/tidak memilih calon tertentu. Berdasarkan hemat penulis bahwa unsur-unsur yang ada tersebut berlaku komulatif apabila hendak disematkan pada tindakan/kualifikasi politik uang.

Beberapa strategi money politik yang dilakukan oleh peserta pemilu ialah antara lain: Pertama Serangan fajar, serangan fajar ialah istilah yang digunakan nuansa pemilihan umum, peserta pemilu menggunakan kekuatan modal (uang,sembako dan bentuk lainnya) dengan memberikan kepada calon pemilih dengan harapan memilihnya, serangan fajar ini lazimnya dilakukan pada saat hampir dilaksanakannya pemungutasn suara (antara masa tenang, sampai menjelang pencoblosan. Kedua, Mobilisasi Massa, mobilisasi massa ialah penggalangan massa dengan pemberian sejumlah uang dengan harapan kampanye yang diadakan dihariri oleh banyak masyarakat/calon pemilih. Pemberian sejumlah uang tersebut dengan dalih pengganti uang transpor, uang lelah dan uang makan.

Terhadap strategi politik uang yang dilakukan oleh peserta pemilu yang pertama (serangan fajar) dalam hal ini, penulis menujukan kesepahaman bahwa tindakan tersebut dapat dikategorikan sebagai pelanggaran politik uang dalam pemilu, sebab biasanya serangan fajar dilakukan pada saat hari tenang serta tindakan yang dilakukan ialah membagi-bagikan uang,sembako dan bentuk materi lain yang memilki nilai ekonomi kepada pemilih untuk memilih satu satu pasangan atau bahkan membeli surat suara yang potensial menurut penilaian pasangan calon tertentu bukan menjadi suaranya dengan cara dibeli agar pemilih tidak dapat menggunakan hak suaramya. Namun yang menjadi sorotan ialah mobilisasi massa yang dilakukan oleh peserta pemilu, Penulis memiliki pandangan yang berbeda dengan pendapat bahwa tindakan mobilisasi massa termasuk tindakan politik uang, namun dengan batasan-batasan/syarat yang menurut penulis perlu diperhatikan. Mobilisasi massa tidak dapat dikategorikan sebagai tindakan/rangkain politik uang dikarenakan beberapa alasan berikut:

1. Penggantian uang transport bukanlah tindakan politik uang

11 Pasal 187A ayat (1) Undang-Undang Nomor 10 Tahun 2016 tentang Pemilihan Kepala Daerah. 
Masa kampanye yang memberikan ruang kepada peserta pemilu untuk mengadakan rangakaian pemilu melalui kampanye terbuka adalah sah dan konstitusional, sebab hal tersebut menjadi hak dari peserta pemilu (telah dijamin oleh Undang-Undang). Dalam lain hal, pelaksanaan kampanye terbuka membutuhkan massa/pemilih yang hadir untuk dapat mengikuti rangkaian peserta pemilu dengan cara meyakinkan pemilih dengan visi dan misi, serta beberapa program kerja yang akan dilakukan kelak jika peserta tersebut terpilih. Meyakinkan pemilih dengan mendeskripsikan visi dan misi serta program kerja yang disusun bukan merupakan pelanggran pemilu karena tindakan tersebut memang hak yang diberikan oleh penyelenggara pemilu untuk meyakinkan pemilih atas beberapa daftar calon pilihan yang ada, sehingga inti dari kampanye terbuka tersebut tidaklah bertentangan dengan konstitusi ataupun UU pemilu.

Hal yang perlu dikaji ialah terkait penggantian uang tranport yang diberikan peserta pemilu terhadap massa/pemilih yang datang ke lokasi acara kampanye. Dalam kultur demokrasi masyarakat indonesia, peran aktif masyarakat akan demokrasi/pelaksanaan pemilu/rangkaian pelaksanaan pemilu sangatlah rendah, pada sisi lain mobilisasi massa/pemilih yang diharapkan hadir memiliki kesibukan tersendiri (dan kesibukan tersebut kesibukan wajib demi kebutuhan pokok kehidupannya), dengan kata lain ada kegiatan rutinitas pemilih yang harus ditinggalkan dari tempat pemilih ke lokasi acara kampanye terbuka tersebut. Bagi sebuah negara yang memiliki kesadaran politik yang tinggi, maka tidak menjadi masalah pemilih datang ke lokasi acara dengan uang tranportasi pribadi yang ia keluarkan sendiri, namun hal tersebut tidak dapat diterapkan terhadap masyarakat yang masih dalam proses menuju ke arah kesadaran politik yang tinggi.

Dengan demikian menurut hemat penulis tindakan tersebut sah dan bukan merupakan tindakan politik uang (money politic) dalam hal pemberian uang transport atas massa/pemilih yang datang ke lokasi bagi mereka (peserta pemilu) yang dengan sengaja tidak menyediakan tranportasi gratis bagi massa/pemilih yang hendak hadir ke acara kampanye terbuka tersebut. Menurut hemat penulis pemberian uang pengganti tersebut sah, sepanjang ketentuan akan penggantian uang tranport tersebut juga diatur sedemikian rupa dan detail (dengan Peraturan Komisi Pemilihan Umum/PKPU) agar terdapat suatu asas keadilan bagi peserta pemilu (jumlah nominalnya ditentukan/agar 
terjadi keseragaman jumlah nominal penggantian uang transport) agar tidak terjadi pemberian uang pengganti tranport yang timpang antara peserta pemilu satu dengan lainnya. Syarat dan pengecualian atas penggantian uang tranport dapat menjadi kategori politik uang apabila aturan standart atas penggantian uang transport tersebut dilanggar dengan cara peserta pemilu memberikan pengganti uang tranport diatas nominal yang telah ditentukan. Pengaturan yang dimaksud dapat dimuat atau dapat diatur dalam peraturan KPU atau peraturan lain yang mengikat.

\section{Penggantian uang lelah dan uang makan bukan tindakan politik uang}

Sama halnya dengan pengganti uang transport, pemberian sejumlah uang dengan dalil uang lelah dan uang makan dalam hal ini tidak dapat dikategorikan sebagai tindakan politik uang (money politic). Hampir sama dengan alasan-alasan yang disampaikan diatas, massa/pemilih datang ke acara kampanye meninggalkan beberapa kegiatan lain yang memiliki sifat ekonomi, sebut saja kebanyakan dari mereka yang datang ialah dari buruh tani, tukang ojek, kuli bangunan dll. Pemberian uang lelah dan uang makan merupakan konversi/pengganti atas kegiatan yang pemilih lakukan dengan mengganti kegiatan di lokasi kampanye sembari meyakinkan pemilih dengan menyampaikain visi, misi dan program kerja peserta pemilu. Jumlah nominal atas penggantian uang lelah dan uang makan seharusnya pula diatur sedemikian rupa agar memiliki keseragaman, pelanggaran atas jumlah nominal yang telah ditentukan tentu dapat dikategorikan politik uang sebab hal tersebut membuat persaingan yang tidak sehat.

Atas kedua alasan tersebut diatas, konsep lain yang sebenarnya dapat dijadikan pedoman agar bentuk pemberian uang (transport, uang lelah dan uang makan) yang dilakukan oleh peserta pemilu terhadap massa/pemilih yang datang ke lokasi acara kampanye terbuka juga melalui penyelenggara agar dapat dilakukan secara fair. Ini merupakan cara kedua yang dapat ditawarakan, peserta pemilu hanya memberikan laporan atas jumlah massa/pemilih yang hendak didatangkan dalam acara kampanye terbuka, serta pemberian uang pengganti atas kompensasi datangnya pemilih ke lokasi acara pelaksanaan kampanye terbuka dilakukan dan disaksikan langsung oleh penyelenggara pemilu (KPU setempat dan Bawaslu setempat), hal ini dirasa cukup tepat untuk menghindari jumlah nominal yang melebihi ketentuan serta jumlah peserta yang 
dilaporkan kepada penyelenggara pemilu, dengan kata lain cara melibatkan penyelenggara pemilu termasuk pengawas pemilu merupakan cara yang cukup efektif agar penggantian uang transport, uang lelah, dan uang makan dilakukan sesuai peraturan perundang-undangan yang disepakati tentang besaran uang penggantian tersebut.

Kebanyakan dari peserta pemilu juga tidak hanya memberikan penggantian atas uang tranport, uang lelah dan uang makan, akan tetapi massa/pemilih yang datang ke lokasi acara kampanye terbuka juga diberikan kaos khusus yang menandakan kaos/atribut tersebut merupakan tanda/ciri khas dari calon perserta pemilu, dalam hal ini masih dalam kategoti dibolehkan atau tidak termasuk tindakan politik uang, ${ }^{12}$ amun akan menjadi tindakan politik uang apabila pemberian kaos diikuti dengan pemberianpemberian materi lain (bahan pokok) sebab yang menjadi dasar penggantian yang disahkan/diperbolehakan atas penggantian dari peserta pemilu terhadap massa/pemilih hanya secara limitatif disebutkan (penggantian uang transport, uang lelah, dan uang makan, yang nominalnyapun telah ditentukan).

Syarat-syarat yang telah dikemukan tersebut diatas sepanjang dilakukan denga benar maka menurut penulis tindakan peserta pemilu atas pemberian sejumlah uang atas kompensasi penggantian uang transport, uang lelah dan uang makan tidak termasuk tindakan politik uang (karena tidak masuk dalam unsur politik uang berdasarkan pasal 187A UU Pilkada dengan dasar tindakan tersebut merupakan konpensasi dan konversi atas kegiatan pemilih yang dialihkan ke tempat/lokasi kampanye terbuka, diadakan pengaturan yang sama terkait besaran penggantian uang transport, uang lelah dan uang makan melalui peraturan perundang-undangan). Selain beberap hal tersebut, terdapat satu hal lagi yang harus diperhatikan agar tindakan tersebut sah, bahwa orasi kampanye yang dilakukan oleh peserta pemilu/juru kampanye pemilu yang ditunjuk tidak boleh mengarahkan pemilih untuk tidak menggunakan hak suaranya apabila calon pemilih tersebut tidak akan memilih calon peserta pemilu yang mengadakan acara kampanye terbuka tersebut, sebab jika hal tersebut dilakukan maka unsur money politik dalam rangkaian kampanye terbuka tersebut dapat dilekatkan dengan dalih terpenuhinya unsur

12 Kaos yang diberikan peserta pemilu merupakan kaos yang merupakan kaos untuk kampanye yang berisi tulisan nama calon peserta pemilu atau gambar. Tidak termasuk/tidak diperkenankan memberikan kaos pada saat kampanyae diluar kualifikasi yang dimaksudkan, misal pemberian kaos yang tidak ada hubungan dengan nama atau gambar dari peserta pemilu. 
Untuk mempengaruhi tidak menggunakan hak pilih (menjadi tidak sah)/tidak memilih calon tertentu, meskipun dibalut dalam nuansa kampanye terbuka peserta pemilu. Dengan demikian kampanye terbuka yang konstitusional juga harus diikuti dengan substansi/materi kampayanye yang tidak bertentangan dengan peraturan perundang-undangan atau dengan kata lain hanya menampilkan sosok/figur peserta pemilu, rekam jejak, visi misi dan program kerjannya.

Kedua, untuk menjawab permasalahan kedua, maka sebenarnya instument hukum yang ada telah cukup baik untuk melakukan tindakan pencegahan politik uang (money politic). Seperti yang telah dijelaskan sebelumnya bahwa instrumen hukum atas pencegahan politik uang ini setidaknya pertama ialah sanksi asminsitasi oleh bawaslu, kedu ialah pemberian sangksi pidana atas tindakan politik uang, dengan ketentuan terbaru yakni dengan Undang-Undang Nomor 10 Tahun 2016 tentang Pemilihan Kepala Daerah, bukan hanya pelaku yang dapat dijerah pasal tindakan politik uang, namun juga pemilih/orang yang menerima uang dari peserta pemilu juga dikenakan pidana atas tindakan menerima uang dalam nuansa pemilu "pidana yang sama diterapkan kepada pemilih yang dengan sengaja melakukan perbuatan melawan hukum menerima pemberian atau janji sebagaimana dimaksud pada ayat (1). ${ }^{13}$ Hukum pidana sebagai ultimum remidium atau upaya terakhir menjadi pilihan yang dapat dilakukan oleh negara/pemerintah untuk mencegah tindakan poltik uang, Namun instumen ini harus harus didukung dengan sosialiasi yang benar dan komprehensif aras seluruh calon pemilih.

Sebagai bahan kajian, sebenarnya ada argumentasi yang menganggap bahwa ketentuan UU 10 Tahun 2016 tentang Pemilihan Kepala Daerah tidak dapat digunakan sebagai ketentuan yang dapat menjerat Peserta dan Pemilih dalam tindakan politik uang (money politic) dalam penyeelenggaran pemilihan umum yang sesungguhnya atau diluar pemilihan kepala daerah (pemilihan Presiden/Wakil Presiden, Pemilihan DPR,DPRD Prov,Kab/Kota. Hal tersebut diakibatkan karena rezim Pemilu Kepalda Daerah bukanlah rezim Pemilu, sehingga Mahkamah Konstitusi (MK) tidak berwenang memeriksa, mengadili, memutus Perselisihan Hasil Pemilu Kepala Daerah. Namun terlepas dari putusan MK Nomor 97/Puu-xi/2013, MK hingga sebelum terbentuk Undang-Undang baru maka MK masih berwenang, namun terlepas dari undang-undang

13 Pasal 187A ayat (2)Undang-Undang Nomor 10 Tahun 2016 tentang Pemilihan Kepala Daerah. 
pemilukada dan pemilu presiden dan wakil presiden, dan pemilu legislatif, yang terpenting dalam kajian ini, instumen hukum sudah dianggap memadai sebagai bentuk untuk mencegak terjadinya politik uang (money politic), sepanjang sebelum tahun 2027 yang direncanakan akan ada pemisahan rezim pemilu dan pemilukada dalam arti yang sesungguhnya.

Menurut penulis instumen hukum tersebut sudah sangat tepat, artinya tindakan politik uang (money politic) juga menyasar mereka yang menerima uang atas nuansa pemilu, apakah ketentuan tersebut benar-benar diketahui dan dimengerti oleh seluruh calon pemilih dalam pemilu, tentu hal tersebut akan menjadi perdebatan, bagi penyelenggara mereka beranggapan bahwa pemilih mengetahui dan mengerti, namun bagi pemilih tidak sedikit bagi mereka, bahkan sampai tulisan ini dibuat mereka tidak mengetahuinya. Sehingga diperlukan sebuah kajian yang mendalam agar ketentuan pencegahan politik uaang (money politic) benar-benar dapat ditarapkan dengan baik.

Ilmu hukum, khususnya ilmu Perundang-undangan ada sebuah asas yang lazim berlaku diseluruh belahan bumi, termasuk di negara indonesia, asas tersebut bernama fiksi hukum (presumtio iures de iure/semua orang dianggap tahu hukum yang sedang berlaku dan mengikat dirinya). Dengan demikian aturan tersebut diatas yang mengatur tentang ancaman bagi penerima politik uang (money politic) haruslah diketahui oleh seluruh pemilih dalam pemilu, ketidaktahuan atas aturan tersebut bukan merupakan pemaaf bagi pemilih yang hendak dikenakan ketentuan tersebut, dalam bahasa latin disebut ignorantia jurist non excusat (ketidaktahuan hukum tidak bisa dimaafkan).

Dengan demikian dalam hal ini sosialisasi yang sungguh-sungguh harus benarbenar dilakukan oleh pemerintah, sebab ketidaktahuan pemilih atas pelanggaran yang dilakukan juga merupakan kesalahan pemerintah jika sosialiasi tidak berjalan sebagaimana mestinya. Dahulu semasa Badan Pembinaan Hukum Nasional (BPHN) masih ada, seluruh elemen berupaya menyebarluaskan setiap peraturan perundangundangan yang diberlakukan oleh negara, namun ketidakadaan BPHN bukan alasan pemerintah mengurangi sosialisasi atas produk hukum perundang-undangan, justru kementerian Hukum dan Ham, penyelenggara pemilu, Pemerintahan Daerah, harus benar-benar tindakan sosialisasi dan penyuluhan hukum, khsusunya dalam konteks ini ialah terkait aturan larangan dilakukannya politik uang (money politic) baik oleh peserta 
pemilu maupun pemilih., hal ini dirasa sangat penting sebab hukum pidana sebagai ultimum remidium akan diterapkan dalam rangka tindakan politik uang.

Peraturan Presiden Nomor 1 Tahun 2007 tentang Pengesahan, Pengundangan dan Penyebarluasan Peraturan Perundang-undangan dengan jelas disebutkan terkait kewajiban menyebarluaskan produk hukum Peraturan Perundang-undangan tersebut, dengan Perpres ini beberapa lembaga ditunjuk sebagai pelaksana untuk melakukan penyebarluasan kepada masyarakat akibat sebuah asas yang telah dijelaskan sebelumnya (fiksi hukum). Pasal 29 ayat (1) "pemerintah wajib menyebarluaskan peraturan perundang-undangan yang telah diundangkan dalam lembaran negara Republik Indonesia dan Berita Negara Republik Indonesia. (2) Pemerintah sebagaimana yang dimaksud pada ayat (1) adalah menteri, sekretariat negara, lembaga sebagaimana dimaksud pada pasal 11, kementerian/lembagapemerintah non departemen yang memprakarsasi rancangan peraturan perundang-undangan yang ditetapkan atau disahkan oleh presiden dan menteri/pimpinan lembaga pemerintah non departemen/pimpinan lembaga sebagaimana dimaksud pada pasal 26 ayat(1). ${ }^{14}$ Ketentuan tersebut muncul oleh karena fiksi hukum diterapakan dalam peraturan perundang-undangan di Indonesia.

Dengan demikian, menurut penulis apabila sosialisasi atau penyuluhan hukum oleh pemerintah dilakukan dengan sebaik-baiknya, maka penulis berkeyakinan ketentuan mengenai pencegahan tindakan politik uang (money politic) akan bekerja dengan baik. Masyarakat/pemilih akan berpikir ulang untuk menerima uang/materi/bentuk materi apapun yang diberikan oleh calon peserta pemilu yang hendak mempengaruhi pilihannya, sebab ada ancaman pidana yang dapat dikenakan kepadanya. Namun sekali lagi perlu ditekankan bahwa instrumen hukum pencegahan politik uang (money politic) dalam pemilu sudah baik namun harus diikuti dengan sosialisasi dan penyuluhan hukum yang sungguh-sungguh agar tidak ada satupun calon pemilih tidak mengetahui aturan yang hendak dikenakan kepadanya dalam penyelenggaran pemilu.

Pembahasan selanjutnya ialah, terkait cara atau mekanisme lain (selain isntrumen hukum positif yang ada) yang dapat bekerja efektif untuk mencegah terjadinya politik uang (money politic) dengan pendekatan budaya/ciri khas masyarakat Indonesia yang

14 Pasal 29 Ayat 1,2 Peraturan Presiden Nomor 1 Tahun 2007 tentang Pengesahan, Pengundangan dan Penyebar luasan Peraturan Perundang-undangan. 
religius. Penulis menawarkan cara/mekanisme penyebarluasan fatwa haram yang telah dikeluarkan oleh Majelis Ulama Indonesia (MUI) tentang fatwa haram politik uang dalam pemilu. ${ }^{15}$

Cara ini merupakan salah satu cara yang dapat dilakukan oleh penyelenggara pemilu dengan menyebarluaskan fatwa haram oleh MUI. Fatwa ini keluar pada hari Rabu 9 Mei 2018 d Banjarbaru, Kalimantan Selatan yang disampaikan langsung oleh Ketua MUI KH. Ma'ruf Amien. Hal ini oleh penulis tawarkan sebab masyarakat indonesia dikenal dengan masyarakat yang religius/keagamaan (khsusnya bagi pemuluk-pemeluk agama islam), bagi pemeluk agama islam sebagain pendapat keagamaan yang disampaikan oleh pemuka agama (ustad, kiai) cenderung banyak diikuti, bahkan mengalahkan ketaatannya pada hukum positif dalam beberapa hal termasuk ancaman hukum pidana, termasuk dalam hal ini ialah fatwa resmi yang dikeluarkan oleh MUI.

Fatwa MUI adalah keputusan atau pendapat keagamaan yang diberikan oleh MUI Indonesia atas persoalan yang berkaitan dengan keagamaan agama islam. Menurut sudut pandang ilmu hukum, keberadaan fatwa MUI ini sebenrnya merupakan accesoris atau tambahan dalam keberagaman hukum yang ada di indonesia, kedudukannya bukan hukum positif sehinga bisa saja negara dan masyarakat tidak mengikuti isi atau fatwa MUI tersebut sehingga sifatnya tidak dapat dipaksakan. Sehingga menurut penulis disini jika terdapat fatwa MUI yang bertentangan atau bahkan bersifat memaksa/power untuk dilaksanakan oleh organisasi kemasyarakatan, negara harus hadir sebagai institusi yang dapat mencegahnya, namun dalam kontek ini, fatwa MUI tentang haram atas penerimaan uang oleh peserta pemilu merupakan fatwa yang sejajar dan mendorong hukum positif yang ada, sehiingga keberadaan Fatwa Haram politik uang (money politic) yang dikeluarkan oleh MUI ini dapat menjadi alternatif peencegahan politik uang dari segi diluar hukum yang ada/hukum positif.

Fatwa MUI tentang fatwa haram politik uang masih tidak begitu banyak diketahui oleh masyarakat banyak, dengan menggunakan bantuan pemuka agama fatwa ini bisa diperluas atau disebarluaskan oleh penyelenggara pemilu dengan memintan bantuan

15 Liputan6.com, "Mui: Politik uang dan pemberian imbalan Hukumnya Haram," m.liputan6.com/news/read/3520539/mui-politik-uang-dan-pemberianimbalan-hukumnya-haram\#, diakses tanggal 11 Oktober 2018. 
pemuka-pemuka agama. ${ }^{16}$ Terlepas sampai tulisan ini dibuat tidak ada peneltian berapa persen keefektifan fatwa keagamaan MUI atas pastisipasi masyarakat, namun dalam beberapa hal fatwa MUI banyak diikuti.

Kenyataan sebagai negara dan masyarakatnya yang religius, terkadang fatwa lebih ampun dari hukum posistif yang diberlakukan oleh negara terhadap rakyatnya, sehingga dalam hal ini perlu sosialisasi besar-besar dan penyebarluasaan informasi tentang fatwa MUI tentang Haram hukumnya menerima uang dari peserta pemilu yang mengarahkan untuk merubah pilihan seseorang/pemilih. Terlebih bagi kalangan pedesaan, kalangan pesantren, alumni pesantre dan kelampok keagaaaan islam yang ada din indonesia, fatwa MUI manjadi pedoman untuk dilaksankan, dan hal tersebut sudah menjadi kebiasaan atau salah satu bentuk ketaatan atas guru/ulama' atas pertanyaan-pertanyaan keagamaan yang telah mendapatkan jawaban oleh MUI.

\section{SIMPULAN}

Kesimpulan atas tulisan ini ialah kualifkasi tindakan politik uang (money politic) tidak serta merta pemberian uang/materi lainnya dari peserta pemilu kepada pemilih, namun tindakan politik uang ialah sebuah tindakan yang unsur-unsur politik uang terpenuhi. bahwa rangkaian kampanye umum terbuka dengan penggantian uang transport, uang lelah dan uang makan bukan merupakan kategori politik uang (money politic), tindakan tersebut merupakan konversi atau kegiatan pelihan yang dialihkan ke acara kampanye terbuka, hal lain agar tindakan penggantiang uang transport, uang lelah dan uang makan tidak menjadi kategoti tindakan politik uang ialah harus diatur melalui peraturan perundang-undangan/PKPU terkait besaran uang pengganti transport, uang lelah dan uang makan, selain itu hal yang perlu diperhatikan dalam acara kampanye terbuka ialah konten/sisi dari kampanye tidak boleh mengarahlan untuk seseorang tidak menggunakan suaranya oleh karena tidak akan memilih calon yang mengadakan kampanye terbuka.

Instumen hukum yang ada sebagai pencegahan politik uang sebenarany sudah bagus untuk mengatasi politik uang dalam pemilu, namun hal tersebut harus tetap

16 Bantuan penyebarluasan atas Fatwa MUI (haram politik uang dalam pemilu) hanya sebatas penyebarluasan isi fatwa MUI, tidak diperkenankan orang yang ditunjuk menggunakan kesematan untuk berkampanye karena sifat yang dimaksud oleh penulis disini ialah penyebarluasan fatwa Haram politik uang yang dikeluarkan oleh MUI, dan termasuk senagkaian tindakan sosialasi penyelenggaran pemilihan umum. 
memprioritaskan sosialisasi dan penyuluhan kepada pemilih karena senyatanya tidak semua orang mengetahui hukum politik uang dalam pemilu, dalam lain hal berlaku fiksi hukum dalam aturan perundang-undangan di Indonesia. Fatwa Haram dari MUI tentang politik uang menjadi salah satu insrtumen yang dapat digunakan oleh penyelenggaran untuk mencegah terjadinya politik uang. Bagi sebagian besar orang di indonesia yang memiliki kultur keagamaan yang baik, fatwa MUI dipandang sebagai hukum atau aturan yang harus mereka taati dan laksanakan.

\section{DAFTAR PUSTAKA}

\section{Buku:}

Asshiddiqie, Jimly. 2010. Konstitusi \& Konstitusioanlisme Indonesia. Jakarta: Sinar Grafika

Gaffar, Abdul. 2009. Pemilu: Sebuah Token of Membership. Yogyakarta: Laboratorium JIP UGM

MD, Mahfud. 2012. Konstitusi dan Hukum dalam Kontoversi Isu. Jakarta : PT. Raja Grafindo Persada

Raws, John. 1971. Theory of Justice. Cambridge: Harvard University Press

Riwanto, Agus. 2016. Hukum Partai Politik dan Hukum Pemilu di Indonesia. Yogyakarta: Thafa Media

\section{Jurnal:}

Sri Utami, Indah, "Pencegahan Politik Uang dan Penyelenggaraan Pilkada yang Berkualitas: Sebuah Revitalisasi Ideologi," Seminar Nasional Hukum, Vol. 2 No. 12016

\section{Internet:}

Berita Satu, "Bawaslu: Pencegahan Politik Uang juga Butuh Partisipasi Masyarakat," http://www.beritasatu.com/politik/46570-bawaslu-pencegahan-politik-uang-jugabutuh-partisipari-rakyat.html, diakses tanggal 11 Oktober 2018 
Kompas.com, "Mahalnya Ongkos Politik," Nasional.kompas.com/read/2018/01//12/ 09494501/mahalnya-ongkos-politik, diakses tanggal 11 Oktober 2018.

Liputan6.com, "Mui: Politik uang dan pemberian imbalan Hukumnya Haram," m.liputan6.com/news/read/3520539/mui-politik-uang-dan-pemberianimbalan-hu kumnya-haram\#, diakses tanggal 11 Oktober 2018

\section{Peraturan Perundang-undangan:}

Republik Indonesia, Undang-Undang Dasar Negara Republik Indonesia Tahun 1945

Republik Indonesia, Undang-Undang Nomor 10 Tahun 2016 tentang Pemilihan Kepala Daerah

Republik Indonesia, Undang-Undang Nomor 7 tahun 2017 tentang Pemilihan Umum

Republik Indonesia, Peraturan Presiden Nomor 1 Tahun 2007 tentang Pengesahan, Pengundangan dan Penyebarluasan Peraturan Perundang-undangan 